\title{
Burkholderia sordidicola sp. nov., isolated from the white-rot fungus Phanerochaete sordida
}

\author{
Young Woon Lim, Keun Sik Baik, Suk Kyun Han, Seung Bum Kim \\ and Kyung Sook Bae
}

Correspondence

Kyung Sook Bae

ksbae@mail.kribb.re.kr

\author{
Korean Collection for Type Cultures, Genetic Resources Center, Korea Research Institute of \\ Bioscience and Biotechnology, 52 Oun-dong, Yusong-ku, Daejon 305-333, Republic of Korea
}

Phanerochaete sordida is a widely distributed white-rot fungal species and is one of the most common corticioid fungi, typically inhabiting fallen branches of hardwood trees (Eriksson et al., 1978; Lim et al., 2000). White-rot fungi degrade lignin more extensively and rapidly than any other organism known (Kondo et al., 1994; Garzillo et al., 1998; Novotný et al., 2000). P. sordida has been applied to a variety of industrial processes, such as biopulping and pulp bleaching, and also used in bioremediation, due to its enzymic capabilities (Lamar et al., 1990).

A range of bacteria that belong to different subdivisions of the Proteobacteria, e.g. Burkholderia fungorum, have been found in association with the white-rot fungus Phanerochaete chrysosporium (Seigle-Murandi et al., 1996; Coenye et al., 2001a).

Burkholderia is a group of metabolically versatile Gramnegative bacteria. The genus was first proposed by Yabuuchi et al. (1992), who transferred seven species of rRNA group II of the genus Pseudomonas to the novel genus on the basis of a polyphasic taxonomic study. Members of the genus Burkholderia are often found in contaminated soil

Published online ahead of print on 9 May 2003 as DOI 10.1099/ ijs.0.02456-0.

The GenBank/EMBL/DDBJ accession numbers for the 16S rDNA sequences of strains KCTC $12081^{\top}$ and KCTC 12082 are AF512826 and AF512827, respectively. and water, as well as in natural soil, water and the rhizosphere of plants, and are capable of degrading numerous low-molecular-mass organic compounds including aromatic compounds, halogenated derivatives and various recalcitrant organic residues (Friedrich et al., 2000; Nogales et al., 2001; Parke \& Gurian-Sherman, 2001).

In an isolation study of $P$. sordida strains collected from the plants Quercus acutissima and Prunus serrulata, bacterial strains were found to be associated with $P$. sordida cultures. Phylogenetic analysis based on 16S rRNA gene sequences indicated that the strains belonged to the genus Burkholderia and that they were apparently distinct from any known species in the genus. Detailed phenotypic and genotypic features of these bacterial isolates are presented in this study.

Strains KCTC $12081^{\mathrm{T}}\left(=\mathrm{JCM} 11778^{\mathrm{T}}\right)$ and KCTC 12082 ( = JCM 11779) were isolated from cultures of the white-rot fungi $P$. sordida KCTC 26213 (collected from Quercus acutissima, Kangwha, Inchon, Korea) and P. sordida KCTC 26214 (collected from Prunus serrulata, Seoul, Korea), respectively. Bacterial strains were subcultured on tryptic soy agar [tryptic soy broth (Difco) supplemented with $1.5 \%$ agar] and grown aerobically at $30^{\circ} \mathrm{C} .16 \mathrm{~S}$ rDNA was PCR-amplified by using primers $27 \mathrm{f}$ and 1492r (Lane, 1991). PCR products were purified by using an AccuPrep PCR Purification kit (Bioneer) and sequenced by using primers 27f, 803f, 907r and 1492r (Lane, 1991). Nearly complete 16S rRNA gene sequences (corresponding to positions 63-1453 
of the Escherichia coli numbering system) were obtained and aligned with those of 23 Burkholderia species with validly published names that were retrieved from GenBank (http://www.ncbi.nlm.nih.gov). Phylogenetic trees based on the neighbour-joining, Fitch-Margoliash and maximumlikelihood methods were inferred by using the PHYLIP package (Felsenstein, 1993). Distances for the first two algorithms were calculated by using the Jukes-Cantor distances option.

DNA-DNA relatedness was determined by using a DIGHigh Prime DNA Labeling and Detection kit (Roche Applied Science) and Bio-Dot SF slot-blotting apparatus (Bio-Rad). Hybridization was performed at $42^{\circ} \mathrm{C}$; labelling of probes, blotting, hybridization and detection were carried out according to the manufacturers' instructions.

The molar $\mathrm{G}+\mathrm{C}$ content of genomic DNA was determined by the thermal denaturation $\left(T_{\mathrm{m}}\right)$ method described by Marmur \& Doty (1962). Major isoprenoid quinones were detected by using the method of Yamada (1998). The Biolog GN system was used according to the manufacturer's instructions to test the degradation of 95 carbon substrates for the two test strains and type strains of eight related species. All tests were run in duplicate.

Cultures of P. sordida KCTC 26213 and KCTC 26214 were always found to be associated with bacterial strains and it was not possible to obtain pure fungal cultures despite repeated trials. In contrast, the bacterial strains could be isolated easily from the mixed cultures and grew well on fungal culture media as well as on complex bacterial media, such as tryptic soy agar. A similar case on P. chrysosporium has been reported previously (Seigle-Murandi et al., 1996; Coenye et al., 2001a).

On agar plates, colonies of strains KCTC $12081^{\mathrm{T}}$ and KCTC 12082 were cream to light ochraceous in colour. No diffusible pigment was produced. Under scanning electron microscopic observation, cells appeared as ovoid to short rod-shaped, approximately $1 \cdot 3-1 \cdot 7 \mu \mathrm{m}$ in length and $1 \cdot 1 \mu \mathrm{m}$ in width (Fig. 1). Cells were non-motile, non-spore-forming and Gram-negative.

Strain KCTC $12081^{\mathrm{T}}$ contained major amount of ubiquinone-8 (UQ-8) (approx. 95\% of total quinones) and also small amounts of UQ-7 (3\%) and UQ-9 $(0.5 \%)$. The genomic DNA G $+\mathrm{C}$ content of the strain, as determined by the $T_{\mathrm{m}}$ method, was $61 \cdot 3 \mathrm{~mol} \%$. Both strains contained hexadecanoic acid $\left(\mathrm{C}_{16: 0}\right)$, cyclo-heptadecanoic acid $\left(\mathrm{C}_{17: 0}\right.$ cyclo) and $\omega$-7-cis-octadecenoic acid $\left(\mathrm{C}_{18: 1} \omega 7 c\right)$ as the major membrane fatty acid components, and also small amounts of 3-hydroxyhexadecanoic acid $\left(\mathrm{C}_{16: 0} 3-\mathrm{OH}\right)$, the presence of which is characteristic for members of the genus Burkholderia (Table 1; Gillis et al., 1995). Morphological and chemotaxonomic properties of the strains were consistent with their classification within the genus Burkholderia (Yabuuchi et al., 1992; Gillis et al., 1995).

The 16S rDNA sequences of strains KCTC $12081^{\mathrm{T}}$ and
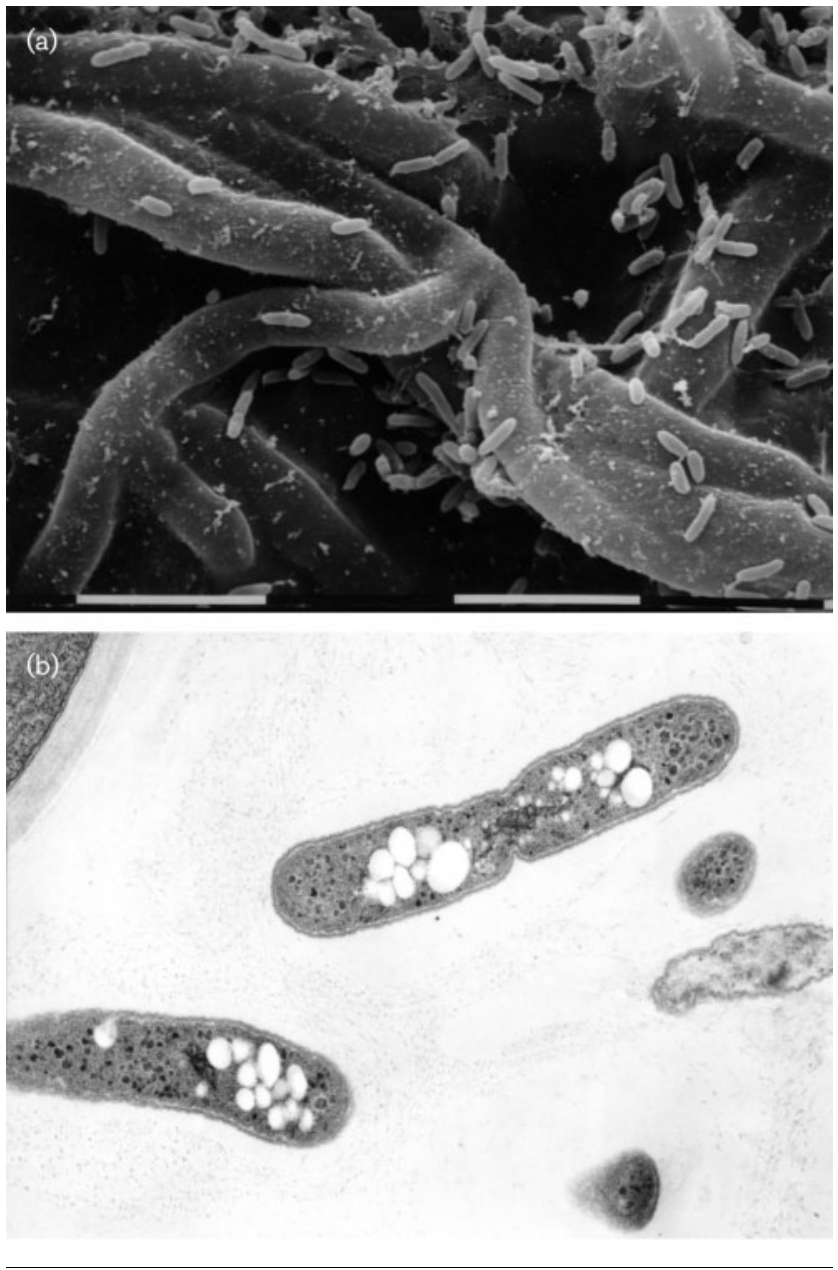

Fig. 1. Electron microscopic images of strain KCTC $12081^{\top}$. (a) Scanning electron microscopic image of KCTC $12081^{\top}$ cells on the surface of fungal mycelia (bars, $10 \mu \mathrm{m}$ ); (b) thinsection image of KCTC $12081^{\top}$ cells taken by transmission electron microscopy. Bright globules within the cell are cellular reserve materials.

KCTC 12082 were found to be identical. The strains were related to Burkholderia glathei ATCC $29195^{\mathrm{T}}$ with $97 \cdot 3 \%$ similarity (corresponding to 38 nucleotide differences out of 1414 positions) and Burkholderia phenazinium LMG $2247^{\mathrm{T}}$ with $97 \cdot 2 \%$ similarity (corresponding to $41 / 1438$ differences). Mean similarity of the 16S rDNA sequence of the test strains against those of 23 Burkholderia species with validly published names was $91 \cdot 6 \pm 0 \cdot 7 \%$. The phylogenetic position of strains KCTC $12081^{\mathrm{T}}$ and KCTC 12082 within the genus Burkholderia is shown in Fig. 2, in which the two strains formed an independent phylogenetic lineage that was related most closely to the clade that included B. glathei and Burkholderia graminis. The two test strains and B. fungorum Coenye et al. (2001a), another species known to be associated with a white-rot fungus (SiegleMurandi et al., 1996), were distantly related as 16S rDNA sequence similarity between the type strains was $96 \cdot 1 \%$ (57/1459 nucleotide differences). The relationship between 
Table 1. Fatty acid composition of selected strains

Strains: 1, KCTC $12081^{\mathrm{T}}$; 2, KCTC 12082; 3, B. glathei KCTC $2968^{\mathrm{T}}$. Numbers indicate percentage values of total amounts.

\begin{tabular}{|lccc|}
\hline Fatty acid & $\mathbf{1}$ & $\mathbf{2}$ & $\mathbf{3}$ \\
\hline $\mathrm{C}_{12: 0}$ & $3 \cdot 3$ & $3 \cdot 04$ & - \\
$\mathrm{C}_{14: 0}$ & $0 \cdot 6$ & $0 \cdot 59$ & $4 \cdot 2$ \\
Summed feature $\mathrm{I}^{*}$ & $3 \cdot 6$ & $3 \cdot 07$ & $4 \cdot 9$ \\
Summed feature $\mathrm{II} \dagger$ & $10 \cdot 2$ & $7 \cdot 45$ & $10 \cdot 5$ \\
$\mathrm{C}_{16: 0}$ & $20 \cdot 9$ & $17 \cdot 49$ & $20 \cdot 2$ \\
$\mathrm{C}_{17: 0}$ cyclo & $19 \cdot 1$ & $23 \cdot 56$ & $18 \cdot 6$ \\
$\mathrm{C}_{17: 0}$ & - & - & $0 \cdot 2$ \\
$\mathrm{C}_{16: 1} 2-\mathrm{OH}$ & $1 \cdot 91$ & $1 \cdot 97$ & $0 \cdot 3$ \\
$\mathrm{C}_{16: 0} 2-\mathrm{OH}$ & $2 \cdot 13$ & $2 \cdot 63$ & $1 \cdot 2$ \\
$\mathrm{C}_{16: 0} 3-\mathrm{OH}$ & $4 \cdot 4$ & $3 \cdot 93$ & $4 \cdot 2$ \\
$\mathrm{C}_{18: 1} \omega 7 c$ & $24 \cdot 3$ & $23 \cdot 28$ & $30 \cdot 5$ \\
$\mathrm{C}_{18: 0}$ & $0 \cdot 76$ & $0 \cdot 69$ & $0 \cdot 6$ \\
$\mathrm{C}_{19: 0} \omega 8 c$ cyclo & $8 \cdot 4$ & $11 \cdot 14$ & $4 \cdot 5$ \\
\hline
\end{tabular}

${ }^{\star}$ Composed of $\mathrm{C}_{14: 0} 3-\mathrm{OH}$ and/or iso- $\mathrm{C}_{16: 1} \mathrm{I}$.

†Composed of $\mathrm{C}_{16: 1} \omega 7 c$ and/or iso- $\mathrm{C}_{15: 0} 2-\mathrm{OH}$.

the test strains and related species in the neighbour-joining tree was not strongly supported by bootstrap analysis and the tree topology around the test strains was not recovered in all other trees generated by different algorithms (Fig. 1). However, the similarity level of $97 \cdot 3 \%$ between the test strains and B. glathei ATCC $29195^{\mathrm{T}}$ is comparable to the values among the 13 species of the Burkholderia cepacia clade, which range between $96 \cdot 1$ and $99 \cdot 9 \%$ with a mean of $98 \cdot 3 \%$.

DNA-DNA relatedness between strain KCTC $12081^{\mathrm{T}}$ and B. glathei KCTC $2968^{\mathrm{T}}$ was $13 \%$ and that between KCTC $12081^{\mathrm{T}}$ and B. phenazinium KCTC $2971^{\mathrm{T}}$ was $15 \%$; both values are well below $70 \%$. These values are comparable to similar cases, for example, $11 \%$ between $B$. cepacia LMG $1222^{\mathrm{T}}$ and Burkholderia gladioli LMG $2216^{\mathrm{T}}$ (sharing $98 \cdot 2 \% 16 \mathrm{~S}$ rDNA sequence similarity) and $36 \%$ between B. cepacia LMG $1222^{\mathrm{T}}$ and Burkholderia vietnamiensis LMG $10929^{\mathrm{T}}$ (sharing 99.4\% $16 \mathrm{~S}$ rDNA sequence similarity) (Vandamme et al., 1997). In another study, all species pairs that shared $>98 \cdot 1 \% 16 \mathrm{~S}$ rDNA sequence similarity resulted in DNA relatedness levels of $<58 \%$ (Coenye et al., $2001 b)$. Thus it is apparent by comparison of $16 \mathrm{~S}$ rDNA sequence and DNA-DNA relatedness that strains KCTC $12081^{\mathrm{T}}$ and KCTC 12082 are sufficiently distant from B. glathei ATCC $29195^{\mathrm{T}}$, B. phenazinium LMG $2247^{\mathrm{T}}$ and other closely related species to be recognized as an independent taxospecies.

The test strains and $B$. glathei were also distinguished by comparison of fatty acid profiles and other phenotypic characteristics (Tables 1 and 2). One major fatty acid component, $\mathrm{C}_{18: 1} \omega 7 c$, exceeded $30 \%$ of the total amount in $B$. glathei, whereas the same component comprised about

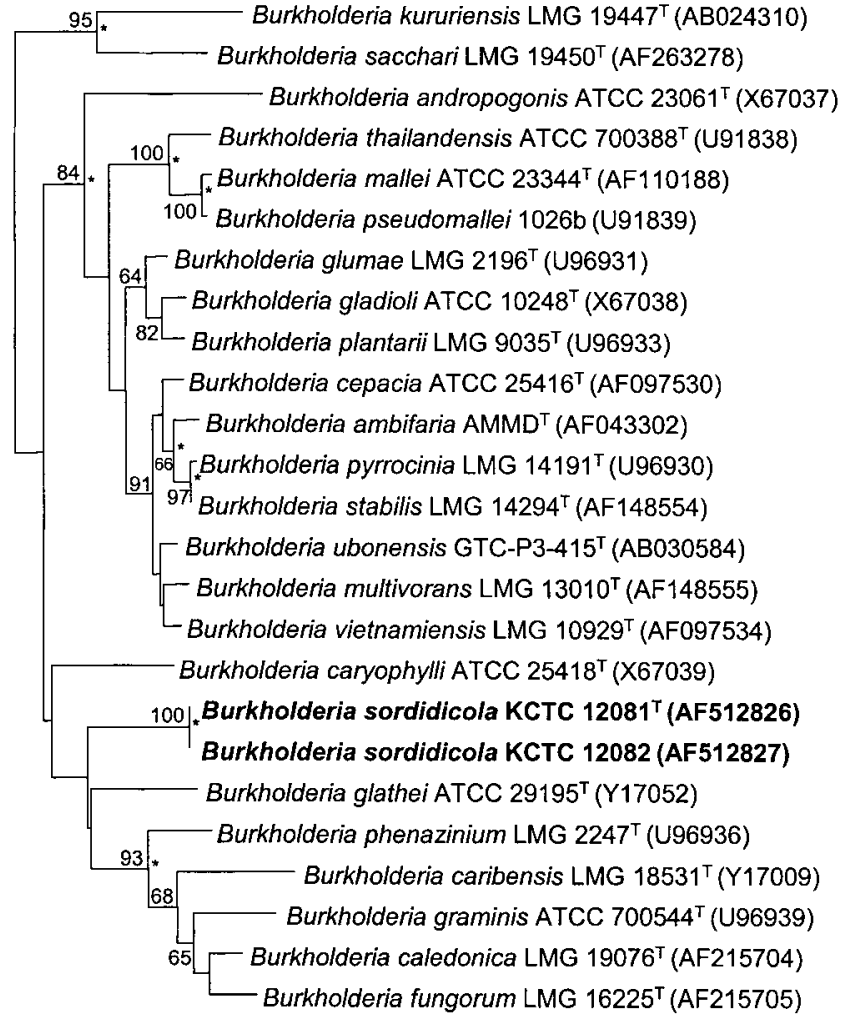

0.01

Fig. 2. Neighbour-joining tree based on 1300 unambiguously aligned positions of representative Burkholderia 16S rDNA sequences. Jukes-Cantor distances were used to construct the distance matrix. Numbers at nodes indicate levels of bootstrap support based on 1000 resamplings and asterisks indicate branches that were also recovered by using the FitchMargoliash and maximum-likelihood methods. Bar, 0.01 substitutions per nucleotide position.

23-24\% in strains KCTC $12081^{\mathrm{T}}$ and KCTC 12082 (Table 1; Vandamme et al., 1997). The two test strains and B. glathei can also be differentiated by motility, as the test strains are not motile but members of $B$. glathei are motile by a polar flagellum (Palleroni, 1984). The Biolog test proved helpful for species discrimination (Table 2). The test strains and closely related species were separated by at least 15 differences, with the exception of KCTC $12081^{\mathrm{T}}$ and B. phenazinium KCTC $2971^{\mathrm{T}}$; these two strains differed in nine tests, but 32 tests out of 83 could not be compared because of the variable results for either strain (Table 2). There were 11 differences between strains KCTC $12081^{\mathrm{T}}$ and KCTC 12082 (Table 2). Tests that showed identical results for all strains, namely 2,3-butanediol, $\alpha$-D-glucose, L-glutamic acid, DL-lactic acid and methyl pyruvate (all positive) and cellobiose, i-erythritol, glycyl L-aspartic acid, $\alpha$-ketovaleric acid, $\alpha$-D-lactose, D-melibiose and thymidine (all negative) were excluded from Table 2.

It is evident that strains KCTC $12081^{\mathrm{T}}$ and KCTC 12082 form a distinct centre of taxonomic variation within the 
Table 2. Carbon source utilization of test strains and related Burkholderia species

Taxa: 1, KCTC $12081^{\mathrm{T}}$; 2, KCTC 12082; 3, B. caribensis KCTC $2964^{\mathrm{T}}$; 4, B. caryophylli KCTC $2965^{\mathrm{T}}$; 5, B. cepacia KCTC $2966^{\mathrm{T}}$; 6 , B. fungorum KCTC $12917^{\mathrm{T}}$; 7, B. glathei KCTC $2968^{\mathrm{T}}$; 8, B. glumae KCTC $2969^{\mathrm{T}}$; 9, B. phenazinium KCTC 2971 ${ }^{\mathrm{T}}$; 10, B. vietnamiensis KCTC $2974^{\mathrm{T}}$. +, Positive; -, negative; $\mathrm{V}$, variable.

\begin{tabular}{|c|c|c|c|c|c|c|c|c|c|c|}
\hline Compound & 1 & 2 & 3 & 4 & 5 & 6 & 7 & 8 & 9 & 10 \\
\hline$\alpha$-Cyclodextrin & - & - & - & - & - & $\mathrm{v}$ & - & - & - & - \\
\hline Dextrin & - & - & - & - & - & + & - & - & - & - \\
\hline Glycogen & - & - & - & - & - & - & - & - & $\mathrm{v}$ & - \\
\hline Tween 40 & $\mathrm{~V}$ & + & + & + & + & + & + & + & + & + \\
\hline Tween 80 & $\mathrm{~V}$ & + & + & + & + & + & + & + & $\mathrm{v}$ & + \\
\hline N-Acetyl-D-galactosamine & - & - & $\mathrm{v}$ & - & - & - & + & - & - & - \\
\hline$N$-Acetyl-D-glucosamine & + & + & + & + & + & - & + & + & + & + \\
\hline Adonitol & + & + & + & - & $\mathrm{V}$ & - & + & + & + & - \\
\hline L-Arabinose & - & $\mathrm{V}$ & + & + & + & - & + & + & - & + \\
\hline D-Arabitol & + & + & + & + & + & - & + & + & $\mathrm{v}$ & + \\
\hline D-Fructose & + & $\mathrm{V}$ & + & + & + & + & + & + & + & + \\
\hline L-Fucose & + & + & + & + & + & - & + & + & + & - \\
\hline D-Galactose & + & + & + & + & + & - & + & + & + & + \\
\hline Gentiobiose & - & - & - & - & - & - & + & - & - & - \\
\hline$m$-Inositol & $\mathrm{V}$ & - & + & + & + & - & + & + & - & + \\
\hline Lactulose & + & - & + & - & + & - & - & - & - & - \\
\hline Maltose & - & - & - & - & - & + & - & - & - & - \\
\hline Mannitol & + & + & + & + & + & - & + & + & $\mathrm{v}$ & + \\
\hline D-Mannose & + & - & + & $\mathrm{v}$ & + & + & + & + & $\mathrm{v}$ & + \\
\hline Methyl $\beta$-D-glucoside & - & - & - & - & - & $\mathrm{v}$ & - & - & - & - \\
\hline D-Psicose & $\mathrm{V}$ & - & - & - & - & + & - & - & $\mathrm{v}$ & - \\
\hline D-Raffinose & - & - & - & - & - & - & - & - & - & + \\
\hline L-Rhamnose & + & + & + & + & + & - & - & - & $\mathrm{v}$ & - \\
\hline D-Sorbitol & + & + & + & + & + & - & + & + & $\mathrm{v}$ & + \\
\hline Sucrose & - & - & - & + & - & - & + & - & - & + \\
\hline D-Trehalose & - & - & + & + & - & + & + & + & - & + \\
\hline Turanose & - & - & - & - & - & $\mathrm{v}$ & - & - & - & - \\
\hline Xylitol & + & - & - & + & + & - & - & - & + & - \\
\hline Monomethyl succinate & $\mathrm{V}$ & + & - & $\mathrm{v}$ & + & - & + & $\mathrm{v}$ & $\mathrm{v}$ & $\mathrm{v}$ \\
\hline Acetic acid & $\mathrm{V}$ & - & $\mathrm{V}$ & - & $\mathrm{V}$ & $\mathrm{v}$ & $\mathrm{v}$ & $\mathrm{V}$ & $\mathrm{v}$ & $\mathrm{v}$ \\
\hline cis-Aconitic acid & - & - & + & + & + & - & + & + & $\mathrm{v}$ & + \\
\hline Citric acid & - & - & + & + & + & - & + & + & $\mathrm{v}$ & + \\
\hline Formic acid & $\mathrm{V}$ & + & + & + & + & - & $\mathrm{v}$ & + & $\mathrm{v}$ & $\mathrm{v}$ \\
\hline D-Galactonic acid lactone & - & + & + & $\mathrm{v}$ & + & - & + & $\mathrm{v}$ & $\mathrm{v}$ & + \\
\hline D-Galacturonic acid & - & - & + & + & + & - & + & - & - & + \\
\hline D-Gluconic acid & + & + & + & + & + & - & + & + & + & + \\
\hline D-Glucosaminic acid & + & + & + & + & + & - & + & + & + & + \\
\hline D-Glucuronic acid & + & - & + & + & + & - & + & - & - & + \\
\hline$\alpha$-Hydroxybutyric acid & $\mathrm{V}$ & $\mathrm{V}$ & + & $\mathrm{v}$ & + & - & $\mathrm{v}$ & - & + & $\mathrm{v}$ \\
\hline$\beta$-Hydroxybutyric acid & + & + & + & + & + & - & + & + & + & + \\
\hline$\gamma$-Hydroxybutyric acid & - & - & - & - & $\mathrm{V}$ & - & - & - & - & - \\
\hline p-Hydroxyphenylacetic acid & - & - & + & + & + & - & + & - & + & $\mathrm{v}$ \\
\hline Itaconic acid & - & - & - & - & + & - & - & - & - & + \\
\hline$\alpha$-Ketobutyric acid & $\mathrm{v}$ & $\mathrm{v}$ & + & - & + & + & + & $\mathrm{v}$ & + & - \\
\hline$\alpha$-Ketoglutaric acid & - & - & + & + & - & - & - & - & + & - \\
\hline Malonic acid & $\mathrm{V}$ & - & $\mathrm{v}$ & $\mathrm{v}$ & + & - & + & + & - & + \\
\hline Propionic acid & - & - & - & $\mathrm{v}$ & + & - & + & + & $\mathrm{v}$ & + \\
\hline Quinic acid & - & + & + & + & + & - & + & + & - & + \\
\hline D-Saccharic acid & - & + & + & + & + & - & + & + & - & + \\
\hline Sebacic acid & $\mathrm{V}$ & + & - & - & $\mathrm{V}$ & - & + & $\mathrm{v}$ & $\mathrm{v}$ & + \\
\hline
\end{tabular}


Table 2. cont.

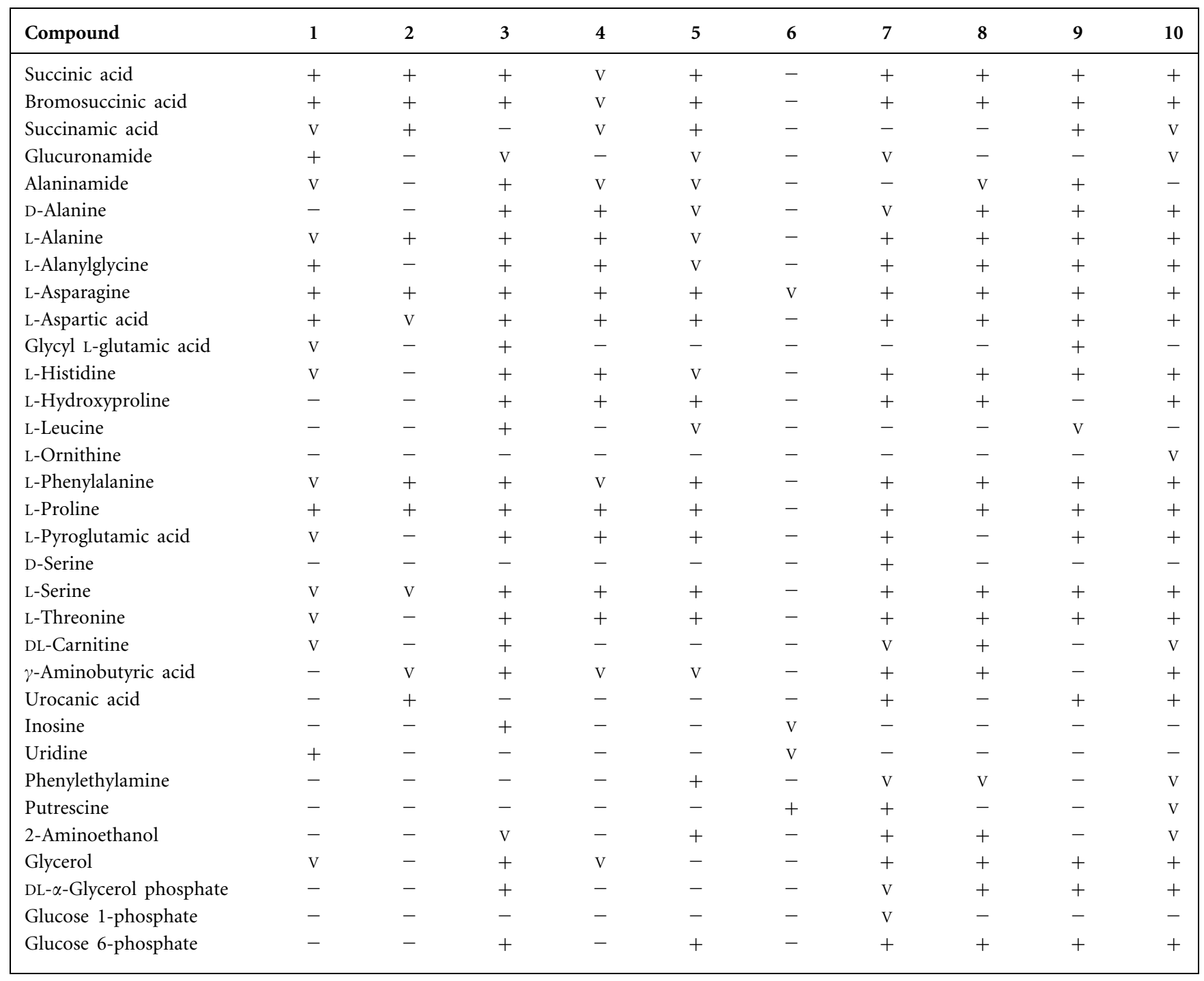

genus Burkholderia. The name Burkholderia sordidicola sp. nov. is proposed to accommodate the test strains, which were associated with the white-rot fungus Phanerochaete sordida.

\section{Description of Burkholderia sordidicola sp. nov.}

Burkholderia sordidicola (sor.di.di'co.la. N.L. n. sordida from Phanerochaete sordida, a species of white-rot fungus; L. suff. n. -cola inhabitant; N.L masc. n. sordidicola inhabitant of Phanerochaete sordida).

Gram-negative, non-motile, non-spore-forming, ovoid to short rod-shaped cells (approx. $1 \cdot 3-1 \cdot 7 \mu \mathrm{m}$ in length and $1 \cdot 1 \mu \mathrm{m}$ in width). Contains major amounts of UQ-8 and small amounts of UQ-7 and UQ-9 in the cell envelope. Major fatty acid components are $\mathrm{C}_{16: 0}, \mathrm{C}_{17: 0}$ cyclo and $\mathrm{C}_{18: 1} \omega 7 c$ and also smaller amounts of a summed feature (composed of iso- $\mathrm{C}_{15: 0} 2-\mathrm{OH}$ and/or $\mathrm{C}_{16: 1} \omega 7 c$ ); $\mathrm{C}_{19: 0} \omega 8 c$ cyclo and $\mathrm{C}_{16: 0} 3-\mathrm{OH}$ are also found. Utilizes a number of carbon compounds, as shown in Table 2. Molar $\mathrm{G}+\mathrm{C}$ content of genomic DNA of the type strain is $61 \cdot 3 \mathrm{~mol} \%$ ( $T_{\mathrm{m}}$ method).

Two strains have been reported to date, both of which were isolated in association with cultures of white-rot fungi that belonged to the species Phanerochaete sordida. Type strain is KCTC $12081^{\mathrm{T}}\left(=\mathrm{JCM} 11778^{\mathrm{T}}\right)$. Reference strain is KCTC 12082.

\section{Acknowledgements}

The authors are grateful to Dr H. W. Oh for obtaining the scanning electron microscopic images and also to E. Y. Moon and Drs S. G. Hong and J. Y. Mheen for help with maintenance of the cultures and phenotypic tests.

\section{References}

Coenye, T., Laevens, S., Willems, A., Ohlén, M., Hannant, W., Govan, J. R. W., Gillis, M., Falsen, E. \& Vandamme, P. (2001a). Burkholderia 
fungorum sp. nov. and Burkholderia caledonica sp. nov., two new species isolated from the environment, animals and human clinical samples. Int J Syst Evol Microbiol 51, 1099-1107.

Coenye, T., Mahenthiralingam, E., Henry, D., LiPuma, J. J., Laevens, S., Gillis, M., Speert, D. P. \& Vandamme, P. (2001b). Burkholderia ambifaria sp. nov., a novel member of the Burkholderia cepacia complex including biocontrol and cystic fibrosis-related isolates. Int J Syst Evol Microbiol 51, 1481-1490.

Eriksson, J., Hjortstam, K. \& Ryvarden, L. (1978). The Corticiaceae of North Europe, vol. 5. Oslo, Norway: Fungiflora.

Felsenstein, J. (1993). PHYLIP (phylogeny inference package), version 3.5c. Department of Genetics, University of Washington, Seattle, USA.

Friedrich, M., Grosser, R. J., Kern, E. A., Inskeep, W. P. \& Ward, D. M. (2000). Effect of model sorptive phases on phenanthrene biodegradation: molecular analysis of enrichments and isolates suggests selection based on bioavailability. Appl Environ Microbiol 66, 2703-2710.

Garzillo, A. M., Colao, M. C., Caruso, C., Caporale, C., Celletti, D. \& Buonocore, V. (1998). Laccase from the white-rot fungus Trametes trogii. Appl Microbiol Biotechnol 49, 545-551.

Gillis, M., Van Van, T., Bardin, R. \& 7 other authors (1995). Polyphasic taxonomy in the genus Burkholderia leading to an emended description of the genus and proposition of Burkholderia vietnamiensis sp. nov. for $\mathrm{N}_{2}$-fixing isolates from rice in Vietnam. Int $J$ Syst Bacteriol 45, 274-289.

Kondo, R., Kurashiki, K. \& Sakai, K. (1994). In vitro bleaching of hardwood kraft pulp by extracellular enzymes excreted from white rot fungi in a cultivation system using a membrane filter. Appl Environ Microbiol 60, 921-926.

Lamar, R. T., Larsen, M. J. \& Kirk, T. K. (1990). Sensitivity to and degradation of pentachlorophenol by Phanerochaete spp. Appl Environ Microbiol 56, 3519-3526.

Lane, D. J. (1991). 16S/23S rRNA sequencing. In Nucleic Acid Techniques in Bacterial Systematics, pp. 115-175. Edited by E. Stackebrandt \& M. Goodfellow. Chichester: Wiley.
Lim, Y. W., Kim, Y. H. \& Jung, H. S. (2000). The Aphyllophorales of Mungyong Saejae. Mycobiology 28, 142-148.

Marmur, J. \& Doty, P. (1962). Determination of the base composition of deoxyribonucleic acid from its thermal denaturation temperature. J Mol Biol 5, 109-118.

Nogales, B., Moore, E. R. B., Llobet-Brossa, E., Rossello-Mora, R., Amann, R. \& Timmis, K. N. (2001). Combined use of $16 \mathrm{~S}$ ribosomal DNA and $16 \mathrm{~S}$ rRNA to study the bacterial community of polychlorinated biphenyl-polluted soil. Appl Environ Microbiol 67, 1874-1884.

Novotný, Č., Erbanová, P., Cajthaml, T., Rothschild, N., Dosoretz, C. \& Šašek, V. (2000). Irpex lacteus, a white rot fungus applicable to water and soil bioremediation. Appl Microbiol Biotechnol 54, 850-853.

Palleroni, N. J. (1984). Genus I. Pseudomonas Migula 1894, $237^{\mathrm{AL}}$. In Bergey's Manual of Systematic Bacteriology, vol. 1, pp. 141-199. Edited by N. R. Krieg \& J. G. Holt. Baltimore: Williams \& Wilkins.

Parke, J. L. \& Gurian-Sherman, D. (2001). Diversity of the Burkholderia cepacia complex and implications for risk assessment of biological control strains. Annu Rev Phytopathol 39, 225-58.

Seigle-Murandi, F., Guiraud, P., Croize, J., Falsen, E. \& Eriksson, K. L. (1996). Bacteria are omnipresent on Phanerochaete chrysosporium Burdsall. Appl Environ Microbiol 62, 2477-2481.

Vandamme, P., Holmes, B., Vancanneyt, M. \& 8 other authors (1997). Occurrence of multiple genomovars of Burkholderia cepacia in cystic fibrosis patients and proposal of Burkholderia multivorans sp. nov. Int J Syst Bacteriol 47, 1188-1200.

Yabuuchi, E., Kosako, Y., Oyaizu, H., Yano, I., Hotta, H. Hashimoto, Y., Ezaki, T. \& Arakawa, M. (1992). Proposal of Burkholderia gen. nov. and transfer of seven species of the genus Pseudomonas homology group II to the new genus, with the type species Burkholderia cepacia (Palleroni and Holmes 1981) comb. nov. Microbiol Immunol 36, 1251-1275.

Yamada, Y. (1998). Identification of coenzyme Q (ubiquinone) homologs. In The Yeasts - a Taxonomic Study, 4th edn, pp. 101-102. Edited by C. P. Kurtzman \& J. W. Fell. Amsterdam: Elsevier. 